УДК 631.17(477.61), DOI 10.31210/visnyk2018.04.02

(C) 2018

Маслійов С. В., доктор сільськогосподарських наук,

Мацай Н. Ю., кандидат сільськогосподарських наук, Циганкова Н. А., аспірант

(науковий керівник - доктор сільськогосподарських наук С. В. Маслійов), Сахно М. А., махістрант

Луганський національний університет ім. Тараса Шевченка

\title{
ВПЛИВ ПОПЕРЕДНИКІВ, ОБРОБІТКУ ГРУНТУ ТА ДОБРИВ НА УРОЖАЙ І ЯКІСТЬ ЗЕРНА КУКУРУДЗИ В УМОВАХ ЛУГАНСЬКОЇ ОБЛАСТІ
}

\section{Рецензент - доктор сільськогосподарських наук I. І. Ярчук}

\begin{abstract}
Урожай більшості польових культур, в тому числі і кукурудзи, залежить від тих умов, які створюються попередніми культурами сівозміни. Розміщення кукурудзи після гарних попередників не лише підвищує урожайність, але і покрашує родючість трунтів.

Встановлено, щуо добрива та обробіток трунту сприяють підвищенню урожайності кукурудзи. $B$ умовах дефіuуиту та дорожнечі мінеральних добрив залишається маловивченим питання заміни їх органічними, які сприяють покращенню екологічного та фітосанітарного стану як трунту, так $i$ посівів кукурудзи, забезпечують отримання кращуого за якістю та дешевого зерна.

У зв'язку з цим, встановлення значення озимої пшениці, ячменю, кукурудзи на зерно і иукрових буряків як основних попередників кукурудзи, вирощуваної на різних фонах удобрення та основного обробітку трунту, в підвищенні ї̈ урожайності набуває особливої актуальності. Досліди проводилися на дослідних ділянках Луганського національного університету ім. Тараса Шевченка в 2016-2018 роках.

Враховуючи важливість проблеми, авторами вказана перспектива на базі комплексних досліджень виявити вплив стерньових та просапних попередників y випадку різних фонів удобрення $і$ обробітку трунту на елементи його родючості, фітосанітарний стан та продуктивність посівів кукурудзи в умовах біологізаиії землеробства.
\end{abstract}

Ключові слова: курудза, попередники, технологія вирощування, добрива, обробка трунту.

Постановка проблеми. Першочерговим завданням сільського господарства України $є$ виробництво продуктів харчування і забезпечення промисловості сировиною. У вирішенні цього завдання велике значення надається кукурудзі як високоврожайній зерновій культурі 3 цінними продовольчими та кормовими якостями.

Урожай більшості польових культур, в тому числі і кукурудзи, залежить від тих умов, які створюються попередніми культурами сівозміни. Розміщення кукурудзи після гарних попередників не лише підвищує урожайність, але і по- кращує родючість грунтів [3].

Встановлено, що добрива та обробіток грунту сприяють підвищенню урожайності кукурудзи. Проте дослідних даних з вивчення комплексної дії та взаємодії попередників, добрив і способів обробітку грунту в умовах північної частини Степу до цього часу ще недостатньо. Зокрема, відсутні експериментальні дані щодо ефективності безполицевого обробітку грунту в разі розміщення кукурудзи після стерньових та просапних передуючих культур. В умовах дефіциту та дорожнечі мінеральних добрив залишається маловивченим питання заміни їх органічними, які сприяють покращенню екологічного та фітосанітарного стану як грунту, так і посівів кукурудзи, забезпечують отримання кращого за якістю та дешевого зерна [4].

У зв'язку з цим, встановлення значення озимої пшениці, ячменю, кукурудзи на зерно і цукрових буряків як основних попередників кукурудзи, вирощуваної на різних фонах удобрення та основного обробітку грунту, в підвищенні іiі урожайності набуває особливої актуальності [1].

Аналіз останніх досліджень і публікацій, у яких започтаковано розв'язання проблеми. За своїми біологічними особливостями кукурудза цілком придатна для вирощування в зоні Степу України. Тут виробництво кукурудзи цілком можливе та рентабельне в разі впровадження ефективної технології вирощування. До важливих елементів агротехніки необхідно віднести раціональне застосування добрив, регуляторів росту, біопрепаратів [7, 8] Вагому роль серед них відіграють мікробіологічні препарати для підсилення фіксації азоту з повітря та мобілізації фосфорних сполук у грунті, оскільки за рахунок цього витрати мінеральних добрив зменьшуються та підвищується реалізація генетичного потенціалу рослин [6].

Не менш важливим фактором є система обробки грунту, оскільки між нею та конкретними 


\section{СІЛЬСЬКЕ ГОСПОДАРСТВО. РОСЛИННИЦТВО}

грунтово-кліматичними умовами існує тісний взаємозв'язок. В останні роки, поряд із використанням традиційних прийомів системи основної обробки грунту, проводиться активна робота 3 впровадження перспективної, економічно вигідної, ресурсозберігаючої та в той же час грунтозахисної технології мулевої обробки грунту, яка передбачає зменшення кількості агротехнічних операцій. Пахоту та культивацію 3 системи нульової обробки виключають, однак інтенсивно використовують гербіциди [3, 4].

Наразі залишаються відкритим питання доцільності та ефективності застосування ресурсозберігаючої системи обробки грунт для підвищення урожайності.

Мета досліджень. Враховуючи важливість проблеми, головною метою нашої роботи було: на базі комплексних досліджень виявити вплив стерньових та просапних попередників за різних фонів удобрення і обробітку грунту на елементи його родючості, фітосанітарний стан та продуктивність посівів кукурудзи в умовах біологізації землеробства. Одночасно з цим, потрібно було дати біоенергетичну оцінку продуктивності кукурудзи залежно від попередників, добрив і способів обробітку грунту.

Завдання досліджень. Потрібно було дати біоенергетичну оцінку продуктивності кукурудзи залежно від попередників. Науково обгрунтувати вплив мінеральних добрив за різних норм їх внесення залежно від фону основного обробітку грунту на ріст, розвиток рослин та зернову продуктивність. Визначити економічні та енергетичні показники моделей технології вирощування кукурудзи.

Матеріали і методи дослідження. Експериментальні роботи проводили в 2016-2018 роки на кафедрі біології Луганського національного університету імені Тараса Шевченка (ЛНУ імені Тараса Шевченка) i на землях Старобільського дослідного господарства ЛНУ імені Тараса Шевченка, розташованого в північно-центральній помірно посушливій підзоні Степової північної зони. Рельєф землекористування дослідного господарства - хвилястий, 3 численними ярами i балками. Поля розташовані на схилах різної довжини і крутизни.

У процесі виконання роботи застосовували спеціальні та загальнонаукові методи досліджень: польовий; візуальний (для реєстрації фенологічних фаз); кількісно-ваговий (для визначення вологості грунту); розрахунковий (для визначення коефіцієнту водоспоживання); лабораторно-хімічний (для визначення вмісту макроелементів у грунті, рослинах та якості зерна); математичної статистики (для оцінки ймовірності одержаних результатів досліджень); розрахунково-порівняльний (для визначення економічної та біоенергетичної ефективності елементів технології вирощування) [2].

Грунти дослідних ділянок - чорноземи звичайні на лесових породах із товщиною гумусового шару 65-80 см. Вміст гумусу в орному шарі грунту (за Тюріним) - 3,8-4,2 \%, валового азоту - 0,21-0,26\%, легкогідролізованого азоту (за Корнфілдом) - 105-150 мг/кг грунту, рухомого фосфору - 84-115 мг/кг і обмінного калію (за Чиріковим) - 81-120 мг/кг грунту. Реакція грунтового розчину була нейтральною або слаболужною. Об'ємна маса шару грунту 0-30 см - 1,30-

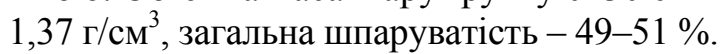

Сума поглинених катіонів досягала 49-54 мгекв. на 100 г грунту. Серед поглинених катіонів $\mathrm{Ca}$ i Mg займали 95-99 \% з співвідношенням між ними 8-9:1. Реакція грунтового розчину була нейтральною або слаболужною (pH 7,0-7,3).

Найменша вологоємність (НВ) метрового шару грунту сягала 24-28 \% (357-399 мм), вологість стійкого в'янення рослин - 12-16 \% (202218 мм). Об'ємна маса шару грунту 0-30 см -

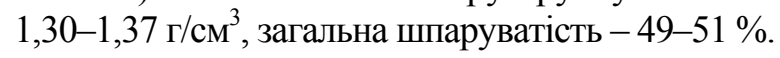

За особливостями рельєфу і грунтового покриву дослідні ділянки були характерними для північно-центральної помірно посушливої підзони Степової північної зони і відрізнялися відносно високою родючістю і сприятливими умовами для вирощування харчових підвидів кукурудзи [4].

За рівнем агрокліматичних факторів територію проведення польових дослідів відносять до північного теплого і посушливого агрокліматичного району, головною особливістю якого є різка континетальність 3 чітко вираженою сезонною контрастністю показників погодно-кліматичних елементів.

Середня річна температура повітря - 7,0-7,2 ${ }^{\circ} \mathrm{C}$. Сума активних температур повітря за період травень - жовтень досягає $3100-3150{ }^{\circ} \mathrm{C}$. Середня місячна температура липня становить 22,0$23,0{ }^{\circ} \mathrm{C}$, січня - $-6,0 \ldots-7,0{ }^{\circ} \mathrm{C}$. Абсолютний максимум температури повітря досягає $40-41{ }^{\circ} \mathrm{C}$, абсолютний мінімум - $-37 \ldots-38^{\circ} \mathrm{C}$. Тривалість безморозного періоду становить 170-175 днів.

Річна сума опадів коливається в межах 450500 мм. Найбільш дощовим місяцем вважається липень - 65-75 мм, а найпосушливішим - вересень - 20-25 мм. Гідротермічний коефіцієнт зволоження (ГТК) за Селяниновим - 0,9-1,0. Ймовірність суховіїв - найнижча по області. За теплий період їх кількість не перевищує 35-37 днів, 
3 них інтенсивних - не більше 3-4 днів.

Клімат - теплий, посилено континентальний, $з$ недостатнім зволоженням. Річне надходження сумарної променистої енергії досягає 105-115 кКал/см², 3 яких 85-92 кКал/см² надходить протягом вегетаційного періоду кукурудзи. Середня річна температура повітря - 8,0 ${ }^{\circ} \mathrm{C}$, середня річна сума температур, більших за $10{ }^{\circ} \mathrm{C}$, досягає 2950-3000 ${ }^{\circ} \mathrm{C}$.

Середня місячна температура липня - 21,5$23,0{ }^{\circ} \mathrm{C}$, січня - $-7,5 \ldots-6,5^{\circ} \mathrm{C}$. Абсолютний максимум температури повітря досягає $40-41^{\circ} \mathrm{C}$, абсолютний мінімум - $-30 \ldots-32^{\circ} \mathrm{C}$. Безморозний період - 150-170 днів.

Середня річна сума опадів не перевищує 450480 мм. Гідротермічний коефіцієнт - 0,9. Суховіїв за теплий період буває в середньому 40-45 днів, 3 них інтенсивних - 10-12 днів.

Останні весняні приморозки в 2016 році спостерігалися в третій декаді травня, у 2017 році - у першій декаді травня, у 2018 році - у першій декаді травня. Перші осінні приморозки - наприкінці вересня - на початку жовтня за середніх багаторічних показників 24 квітня та 4 жовтня.

Таким чином, у цілому грунтові та кліматичні умови є сприятливими для вирощування харчових підвидів кукурудзи. Але значні коливання родючості грунтів та погодно-кліматичних умов значно впливають на ріст, розвиток та урожайність кукурудзи й потребують їх урахування під час розробки технологій вирощування цих підвидів кукурудзи [6].

Результати досліджень. Нормальний розвиток рослин кукурудзи визначається не лише необхідними запасами вологи, але також й іншими факторами, серед яких важливе місце займає наявність у грунті доступних поживних речовин. Для кукурудзи, яка вирощується на чорноземах звичайних, це перш за все, сполуки азоту та фосфору.

Значна частина азоту у грунті існує у вигляді органічних речовин, які недоступні для безпосереднього споживання рослинами. Поступова мобілізація органічних сполук грунту у форми, які стають доступними рослинам, відбувається в процесі життєдіяльності грунтової мікрофлори. Досліджуючи поживний режим грунту під посівами кукурудзи, приходять до висновку, що культурні рослини, які передують кукурудзі у сівозміні, відрізняються неоднаковою спроможністю використовувати поживні речовини 3 різ- них поміжних сполук.

Такому явищу сприяють особливості та характер мікробіологічної та ферментативної активності у грунті під різними культурами польової сівозміни. При цьому відмічається, що ферментативні процеси, які забезпечують розклад органічних рештків, які лишаються у грунті після збирання попередника, інтенсивніше відбуваються під просапними культурами, ніж під зерновими, що певним чином відображається на вмісті поживних речовин для наступних посівів кукурудзи[3].

Численними дослідженнями виявлено, що кукурудза є культурою, вимогливою до рівня родючості грунту, оскільки ця культура $з$ урожаєм виносить 3 грунту значну кількість елементів живлення. На утворення одиниці урожаю кукурудза споживає майже стільки ж сполук азоту та фосфору, як озима та яра пшениця, жито або овес. За рівнем виносу цих сполук вона поступається лише соняшнику. Згідно 3 даними, які були отримані у Луганській області, кукурудза 3 одного гектару виносить 116,7-121,8 кг азоту, 43,7-48,2 кг фосфору та 90,3-94,3 кг калію [4].

Але ці показники не $\epsilon$ незмінною величиною - в значній мірі вони залежать від попередників, погодних умов, добрив та урожаю у конкретні роки.

Головним джерелом азоту для живлення рослин $\epsilon$ солі азотної кислоти та амонію. Подальшими дослідженнями було встановлено, що у чорноземних грунтах рівень азотного живлення сільськогосподарських культур визначається, головним чином, вмістом нітратів. Забезпечення ж рослин кукурудзи цим елементом живлення в умовах степової зони України в значній мірі залежить від попередників, оскільки після їх збирання у грунті лишається різна кількість нітратного азоту. Так, згідно з даними, після збирання озимої пшениці та гороху вміст азоту у грунті був практично однаковим (8-10 кг/га), а після кукурудзи - у два рази вищим (16 кг/га). У період від збирання попередника до сівби кукурудзи кількість нітратного азоту збільшувалась після озимої пшениці у 4-4,5 рази, після гороху - у 3,5 рази, а після кукурудзи - лише вдвічі.

Результати наших досліджень показали, що на початок сівби кукурудзи дещо більше нітратів накопичувалось у грунті після другої озимої пшениці по чорному пару та після цукрового буряка, найменше - після кукурудзи (табл. 1). 
СІЛЬСЬКЕ ГОСПОДАРСТВО. РОСЛИННИЦТВО

\section{1. Динаміка нітратного азоту у шарі трунту 0-40 см під посівами кукурудзи після різних} попередників, мг/кг (середнє за 2016-2018 роки)

\begin{tabular}{|l|c|c|c|}
\hline \multirow{2}{*}{ Попередники } & \multicolumn{3}{|c|}{ Строки визначення } \\
\cline { 2 - 4 } & Під час сівби & $\begin{array}{c}\text { Під час викидання } \\
\text { волотей }\end{array}$ & Під час збирання \\
\hline $\begin{array}{l}\text { Озима пшениця другого року } \\
\text { по чорному пару }\end{array}$ & 21,0 & 15,9 & 13,0 \\
\hline Ячмінь & 19,1 & 16,0 & 14,8 \\
\hline Кукурудза на зерно & 18,6 & 16,2 & 14,3 \\
\hline Цукровий буряк & 24,0 & 17,1 & 15,6 \\
\hline
\end{tabular}

2. Вилив способів обробітку грунту на запаси нітратного азоту у трунті під посівами кукурудзи після озимої пшениці, мг/кг (середнє за 2016-2018 роки)

\begin{tabular}{|c|c|c|c|c|}
\hline \multirow{2}{*}{ Способи обробітку грунту } & \multirow{2}{*}{$\begin{array}{c}\text { Шари грунту, } \\
\text { см }\end{array}$} & \multicolumn{3}{|c|}{ Строки визначення } \\
\cline { 3 - 5 } & & Під час сівби & $\begin{array}{c}\text { Під час вики- } \\
\text { дання волотей }\end{array}$ & $\begin{array}{c}\text { Під час } \\
\text { збирання }\end{array}$ \\
\hline \multirow{2}{*}{ Полицева оранка } & $0-20$ & 25,4 & 20,7 & 15,6 \\
& $20-40$ & 16,6 & 11,1 & 10,5 \\
\hline \multirow{2}{*}{ Чизельний обробіток } & $0-20$ & 25,6 & 15,4 & 13,1 \\
& $20-40$ & 17,4 & 13,2 & 12,3 \\
\hline
\end{tabular}

Більший вміст $\mathrm{NO}_{3}$ після озимої пшениці пояснюється кращими умовами мінералізації органічного азоту після неї за рахунок гарної вологозабезпеченості верхнього шару грунту. Зменшення вмісту азоту після кукурудзи у порівнянні 3 озимою пшеницею обумовлюється високим рівнем виносу сполук цього елементу з іiі урожаєм. Цукровий буряк теж виносить 3 урожаєм дуже багато азоту, ці втрати компенсуються за рахунок внесення у грунт під цю культуру більшої кількості добрив. Крім того, завдяки кореневій системі, яка глибоко проникає у грунт, ця культура поглинає нітрат-іони з більшого об'єму грунту, в той час як $80 \%$ урожаю кукурудзи на чорноземних грунтах утворюється за рахунок елементів живлення із шару грунту 0-35 cм.

В інші строки визначення кількісна різниця щодо вмісту нітратів у грунті після різних попередників стає менш помітною і математично не підтверджується. Але спостерігається поступове зниження вмісту нітратного азоту в грунті впродовж вегетації, яке пов'язане $з$ його витратами на утворення біомаси рослин кукурудзи, а також із зменшенням інтенсивності мікробіологічної діяльності у пересушеному верхньому шарі грунту.

Способи основного обробітку грунту можуть впливати на поживний режим грунту. Більше нітратів $(34,6$ мг/кг) містить в собі грунт, який піддавався безполицевому обробітку. Оранка на 25-27 см забезпечувала, у порівнянні з чизельним обробітком, нижчий рівень вмісту нітратів. Зменшення вмісту нітратного азоту у верхньому шарі грунту за безполицевого обробітку у порівнянні 3 полицевою оранкою. У багаторічному стаціонарному досліді заміна полицевої оранки щорічним безполицевим обробітком на $10-12 \mathrm{~cm}$ під зернові і 30-32 см під просапні не вплинула на валові запаси азоту, фосфору та калію. Кількість нітратів в орному шарі може бути однакова під час застосування як полицевої оранки, так безполицевого обробітку. Але заміна глибокого обробітку мілкішим може сприяти зниженню нітрифікаційної спроможності грунту, знижуючи тим самим вміст у грунті доступних рослинам форм азоту.

Результати наших досліджень свідчать про те, що у всі строки визначення способи обробітку грунту математично підтвердженого впливу на вміст нітратного азоту (в середньому у шарі 0-40 см) не мали (табл. 2).

Деяке зменшення кількості нітратів у верхньому шарі грунту під час застосування безполицевого обробітку у порівнянні з полицевою оранкою пов'язана 3 тим, що наявність великої кількості пожнивних залишків у ньому навесні стимулює значне посилення життєдіяльності грунтової мікрофлори, на що використовується певна частина запасів нітратного азоту грунту. Зменшення кількості солей азотної кислоти після застосування безполицевого обробітку можна пояснити також деякими змінами агрофізичних властивостей грунту, зокрема, підвищеною щільністю шару грунту 20-40 см у порівнянні 3 грунтом, який піддавався полицевій оранці. 


\section{СІЛЬСЬКЕ ГОСПОДАРСТВО. РОСЛИННИЦТВО}

Внесення адекватних доз добрив дає змогу компенсувати втрати кількості поживних речовин, які винесені передуючою культурою з урожаєм, відновити та підтримувати початковий рівень родючості грунту і створити сприятливі умови для отримання гарного урожаю наступної культури. Великі труднощі із забезпеченням господарств мінеральними добривами, які зумовлені загальною кризою економіки нашої країни, зробили актуальними дослідження відносно впливу добрив, зокрема, органічних місцевого походження, на вміст нітратів у грунті.

Аналіз вмісту нітратів у грунті залежно від застосовуваних добрив дає змогу прийти до висновку, що ні одні, ні другі по цьому показнику не мають переконливої переваги у всі строки визнання (табл. 3).

Для більш об'єктивної оцінки рівня забезпеченості рослин кукурудзи нітратним азотом були проведені дослідження по визначенню нітрифікаційної спроможності грунту ті ж строки. Вміст та накопичення нітратів у грунті взаємопов'язане 3 нітрифікацією, рівень якої визначає культурний стан грунту, де існують сприятливі умови як для життєдіяльності корисної мікрофлори, так і для нормального розвитку сільськогосподарських рослин. Нітрифікаційна спроможність зале- жить не тільки від властивостей грунту (вміст гумусу, загального азоту, реакції грунтового розчину, агрофізичних характеристик), але і від біологічних особливостей вирощуваних кукурудз, кількості внесених добрив, способів обробітку грунту.

Визначення нітрифікаційної спроможності у наших дослідах дало змогу виявити, що у грунті після різних попередників вона була значно вищою, ніж у контролі (табл. 4).

На час початку збирання кукурудзи рівень нітрифікаційної спроможності удобрених ділянок дещо знижувався (на 19-32 \%), що пояснюється пересиханням верхнього шару грунту, яке ускладнює умови для протікання процесу нітрифікації.

Фон добрив впливає на рівень нітрифікаційної спроможності. Нижчий їі рівень характерний для грунту неудобрених посівів, різниця між застосовуваними фонами добрив практично відсутня впродовж усієї вегетації (табл. 5).

Рівнозначний вплив на цей показник мали $\mathrm{i}$ способи обробітку грунту: після застосування полицевої оранки у шарі грунту 0-40 см під час сівби він становив 18,6 мг/кг, а за чизельного обробітку $-19,1$.

\section{3. Дія добрив на вміст нітратного азоту у грунті під посівами кукурудзи після озимої пшениці,}

мг/кг (середне за 2016-2018 роки)

\begin{tabular}{|c|c|c|c|c|}
\hline \multirow{2}{*}{ Удобрення грунту } & \multirow{2}{*}{$\begin{array}{c}\text { Шари грунту, } \\
\text { см }\end{array}$} & \multicolumn{3}{|c|}{ Строки визначення } \\
\cline { 3 - 5 } & Під час сівби & $\begin{array}{c}\text { Під час викидан- } \\
\text { ня волотей }\end{array}$ & Під час збирання \\
\hline \multirow{2}{*}{ Без добрив } & $0-20$ & 25,4 & 20,7 & 15,6 \\
& $20-40$ & 16,6 & 11,1 & 10,5 \\
\hline \multirow{2}{*}{ Добрива: органічні } & $0-20$ & 26,3 & 21,2 & 16,0 \\
& $20-40$ & 15,2 & 13,4 & 11,4 \\
\hline \multirow{2}{*}{ мінеральні } & $0-20$ & 29,8 & 22,1 & 13,5 \\
& $20-40$ & 16,7 & 13,2 & 10,9 \\
\hline
\end{tabular}

4. Нітрифікаційна спроможність удобреного грунту в шарі 0-40 см під посівами кукурудзи після різних попередників, мг $\mathrm{NO}_{3}$ на 1 кг абсолютно сухого грунту після 7-денного компостування (середнс за 2016-2018 роки)

\begin{tabular}{|l|c|c|c|}
\hline \multicolumn{1}{|c|}{ Попередники } & \multicolumn{3}{|c|}{ Строки визначення } \\
\cline { 2 - 4 } & Під час сівби & $\begin{array}{c}\text { Під час викидання } \\
\text { волотей }\end{array}$ & Під час збирання \\
\hline $\begin{array}{l}\text { Озима пшениця другого року по } \\
\text { чорному пару }\end{array}$ & 18,6 & 16,2 & 14,8 \\
\hline Ячмінь & 21,3 & 20,2 & 17,3 \\
\hline Кукурудза на зерно & 18,5 & 19,2 & 16,1 \\
\hline Цукровий буряк & 22,2 & 23,7 & 14,6 \\
\hline $\begin{array}{l}\text { Контроль (3-річний посів куку- } \\
\text { рудзи) }\end{array}$ & 16,1 & 13,3 & 14,2 \\
\hline
\end{tabular}


5. Нітрифікаційна спроможність трунту у шарі 0-40 см під посівами кукурудзи після озимої пшениці залежно від його удобрення, мг $\mathrm{NO}_{3}$ на 1 кг абсолютно сухого трунту після 7-денного компостування (середне за 2016-2018 роки)

\begin{tabular}{|c|c|c|c|}
\hline \multirow[b]{2}{*}{ Удобрення грунту } & \multicolumn{3}{|c|}{ Строки визначення } \\
\hline & Під час сівби & $\begin{array}{c}\text { Під час викидання } \\
\text { волотей }\end{array}$ & Під час збирання \\
\hline Без добрив & 18,6 & 16,2 & 14,8 \\
\hline органічні & 22,8 & 20,2 & 15,2 \\
\hline мінеральні & 22,3 & 19,0 & 15,4 \\
\hline
\end{tabular}

Висновки. Таким чином, наші дослідження дали змогу виявити, що дещо краще забезпечені нітратним азотом посіви кукурудзи, які у сівозміні розташовані після другої озимої пшениці

\section{БІБЛІОГРАФІЯ}

1. Валитов А. В. Формирование агроценозов кормовых культур в промежуточных посевах / А. В. Валитов. - Вестник БГАУ, № 3, 2011. - С. 12-20

2. Доспехов Б.А. Методика полевого опыта (с основами статистической обработки результатов исследований) / Б. А. Доспехов. - М. : Агропромиздат, 1985. - $351 \mathrm{c.}$

3. Киреев В. М. Кормовые культуры в промежуточных посевах / В. М. Киреев, В. Д. Клинов - Степные просторы, № 4, 1986. - С. 38-39.

4. Маслійов С. В. Вплив біопрепаратів на харчові підвиди кукурудзи (монографія) / С. В. Маслійов, Н. Ю. Мацай, Є. С. Маслійов. - ДЗ «ЛНУ імені Тараса Шевченка», 2018. - 163 с.

\section{ANNOTATION}

Masliiov S. V., Matsai N. Yu., Tsyhankova N. A., Sakhno M. A. Effect of predessors, soil cultivation and fertilization on the harvest and the quality of cereal grains of corn in the conditions of Luhansk region.

The harvest of most field crops, including corn, depends on those conditions which are pre-crops in the rotation. The location of the corn after a good predecessors not only increases the yield, but also improves soil fertility.

It has been established that fertilizers and soil cultivation help to increase the yield of corn. In the conditions of deficit and high cost of mineral fertilizers, the issue of their replacement by organic, which helps to improve the ecological and phytosanitary state of both soil and corn, remains weak, providing quality and cheap grain products.

In this regard, the determination of the value of по чорному пару та цукрового буряка.

Досліджувані системи добрив та обробітку грунту за рівнем впливу на цей показник суттевих відмінностей не мали.

5. Маслійов С. В. Розлусна кукурудза на Сході України / С. В. Маслійов. - Луганськ : видавництво «Шлях», 1999. - 154 с.

6. Посыпанов Г. С. Растениеводство / Г. С. Посыпанов. - М. : Колос, 2006. - 612 с.

7. Носко Б. С. Сучасний стан та перспективні напрямки досліджень в агрохімії / Б. С. Носко // Вісн. аграр. науки. - 2002. - №9. - С. 9-12.

8. Патыка В.Ф. Агроэкологическая роль азотфиксирующих микроорганизмов / В. Ф. Патыка. - К., 2004. - 320 с.

9. Ситник В. П. Екологічні аспекти агропромислового комплексу / В. П. Ситник // Вісник аграрної науки. - 2002. - №9. - С. 55-57.

winter wheat, barley, maize for grain and sugar beet, as the main predessors of maize, grown on different backgrounds of fertilizer and basic cultivation of soil, in increasing its yield is of a particular relevance. Experiments were conducted on experimental areas of Luhansk Taras Shevchenko National University in 2016-2018.

Taking into account the importance of the problem, the authors pointed out the prospect on the basis of complex studies to determine the effect of stems and propagation predessors at different backgrounds of fertilization and soil cultivation on elements of its fertility, phyto-sanitary condition and productivity of corn crops in the conditions of agriculture biologization.

Key words: corn, predessors, growth technology, fertilization, soil cultivation. 